\title{
A Case of Fibromatosis Occurring in the Levator Scapulae
}

\author{
Eung-Hyub Kim, Gun-Ho Lee, Bon Seok Koo and Yeo-Hoon Yoon \\ Department of Otolaryngology-Head and Neck Surgery, Chungnam National University School of Medicine, Daejeon, Korea
}

\section{견갑거근에 발생한 섬유종증 1 예}

김응협· 이건호 · 구본석 · 윤여훈

충남대학교 의과대학 이비인후-두경부외과학교실

\author{
Received August 12, 2009 \\ Revised November 5, 2009 \\ Accepted November 5, 2009 \\ Address for correspondence \\ Yeo-Hoon Yoon, $\mathrm{MD}, \mathrm{PhD}$ \\ Department of Otolaryngology- \\ Head and Neck Surgery, \\ Chungnam National University \\ School of Medicine, 640 Daesa-dong, \\ Jung-gu, Daejeon 301-721, Korea \\ Tel $+82-42-280-8375$ \\ Fax +82-42-253-4059 \\ E-mail yyh9635@cnuh.co.kr
}

Fibromatosis is a benign tumor arising from the musculoaponeurotic tissues of the body. The natural history of fibromatosis is slow, progressive growth with invasion of adjacent tissues but this tumor has no malignant or metastatic potential. Complete surgical excision is the mainstay of treatment. However, it is often difficult due to the complex anatomy, close proximity of vital structures in the head and neck region. Preoperative core needle biopsy and MR images can make it possible to diagnose preoperatively and outline the tumor extent, which are very important to treat patients with fibromatosis. In this report, a rare case of fibromatosis occurring in the levator scapulae muscle is presented with a review of literatures.

Korean J Otorhinolaryngol-Head Neck Surg 2009;52:1001-4

Key Word Fibromatosis.

\section{서 론}

섬유종증(fibromatosis)은 근건막계의 섬유아세포가 증 식하여 발생하는 드문 질환이다. 이 질환은 조직학적으로 양 성이지만 주위 조직을 잘 침범하며 절제 후 국소재발을 잘하는 경향이 있다. ${ }^{1,2)}$ 두경부는 경동맥, 기관, 식도, 뇌신경 등 중요 한 구조물이 많고 근막면이 복잡하여, 두경부에 발생한 섬유종 증의 경우 완전 절제가 어려운 경우가 많아 재발률이 높다. ${ }^{3)}$

두경부 영역에 발생한 섬유종증은 국내 문헌에 몇몇 증례 가 보고되어 있으나, 흔히 접하는 질환은 아니어서 술 전 진단이 어려워 대부분 술 후 조직검사를 통해 진단되는 경우가 많다. ${ }^{4-6)}$

저자들은 우측 후경부의 종물을 주소로 내원한 여성에서 다양한 영상검사와 중심부 바늘 생검(core needle biopsy) 을 시행하여 술 전에 섬유종증을 진단하고 치료했던 증례를 경험하여 문헌고찰과 함께 보고하고자 한다.

\section{증 례}

52세 여자 환자가 수개월 전부터 서서히 커지는 우측 경
부 종물을 주소로 내원하였다. 우측 측경부의 종물은 $5 \mathrm{~cm}$ 정도의 크기로 단단하였고 약간의 가동성은 있었다. 촉진시 압통을 없었지만 종물을 중심으로 둔통을 호소하였고 신체 검사에서 다른 이상 소견은 없었다.

내원 전 외부 병원에서 시행한 경부 초음파검사에서 불균 질한 낮은 에코음영을 보이는 난형의 종물이 관찰되어 연부조 직 종양이 의심되었다. 2 차례의 세침흡인세포검사에서 조직구 성 세포와 육아조직이 일부 관찰되었으나 진단을 하기에는 부족하였다. 경부 전산화단층촬영에서도 우측 측경부 심부 근 육의 비후만 관찰되었다. 연부조직에 대해 보다 정확한 검사 를 위해 자기공명영상을 촬영하였다. $\mathrm{T} 1$ 강조영상에서 저신 호 강도를, $\mathrm{T} 2$ 강조영상에서 고신호 강도를 보이며 조영 증 강되는 침윤성 연조직 종물이 우측 견갑거근 부위에서 관찰 되어 섬유종증 혹은 혈관종 등이 의심되었다(Fig. 1). 초음 파 유도 하에 자동총생검(automated gun biopsy)을 시행하 여 조직검사를 의뢰하였다. 조직검사결과 방추형 섬유아세 포의 증식을 보이는 섬유종증으로 진단되었다.

미용과 기능면에서 장애는 없었지만 종물이 지속적으로 커 지고 있어 수술을 시행하였다. 병변 부위에서 횡절개를 가한 
후 피판을 거상하였다. 척수부신경을 보존하면서 종물 상방 의 지방조직을 제거하여 병변을 노출하였다. 종물은 우측 견 갑거근을 중심으로 중사각근(midscalene muscle) 과 연접해 있었고 경신경총 기원의 감각신경과 횡격막신경 등을 침범 하고 있었으나 상완신경총의 침범은 없었다(Fig. 2). 침범 된 근육과 신경을 포함하여 종물을 절제하였다. 육안 소견 으로는 검체는 $5 \times 3 \mathrm{~cm}$ 크기의 백색 종물로 주위 근육을 침윤하고 있으며 경계는 불분명하였다(Fig. 3A). 조직병리 소견은 술 전과 동일하였고, 중요한 신경이 연접해 있어 충
분한 절제연을 확보하지는 못했지만 절제연에서 종양은 음 성이었다(Fig. $3 \mathrm{~B}$ ). 술 후 우측 횡격막 마비 이외에 다른 이상 소견은 없었으며 10 개월째 외래 추적관찰 중으로 재 발 소견은 없다.

\section{고 찰}

섬유종증은 결합조직형성 섬유종(desmoplastic fibroma), desmoma, 공격성 섬유종증(aggressive fibromatosis), 섬
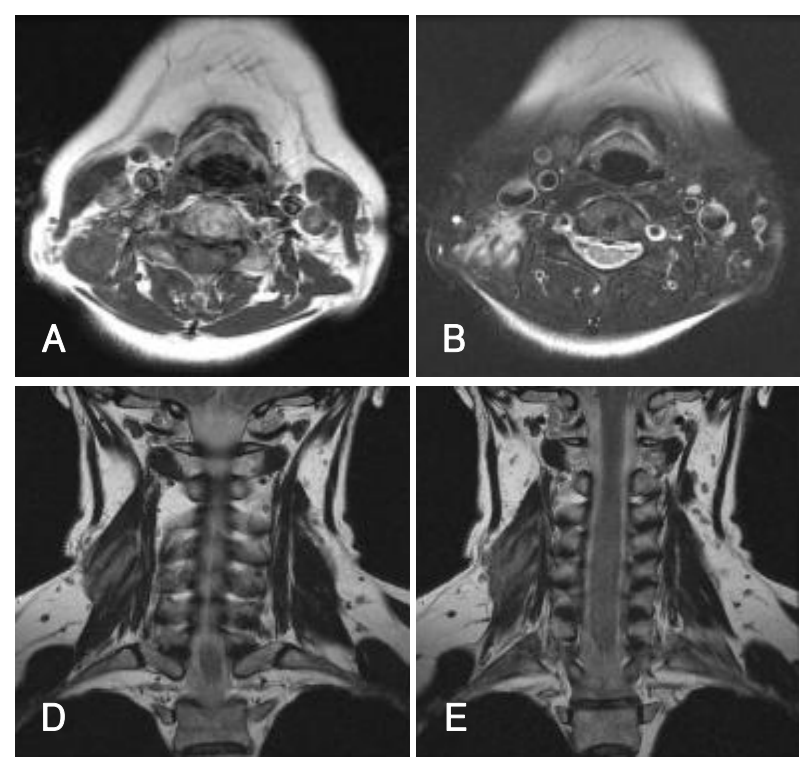

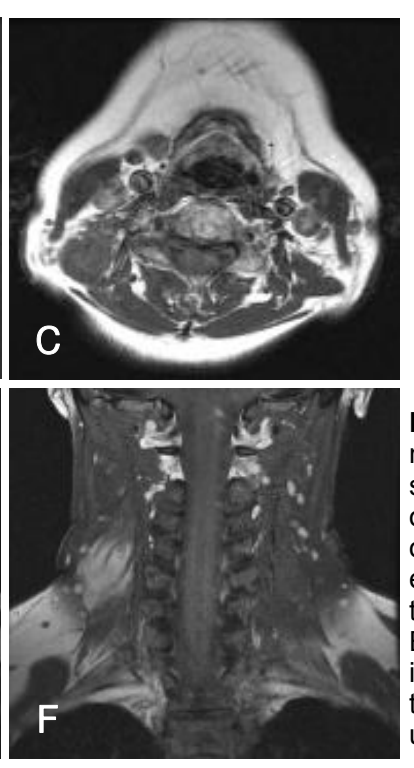

$\sqrt{1}$

Fig. 1. Preoperative axial and coronal MR images. Infiltrative soft tissue lesion along the muscle bundle of right levator scapulae muscles shows low signal intensity in T1-weighted images ( $A$ and $D)$, high signal intensity in T2-weighted images (B and $E)$, and avid contrast enhancement in T1-weighted images obtained after intravenous injection of gadolinium ( $C$ and $F$ ).

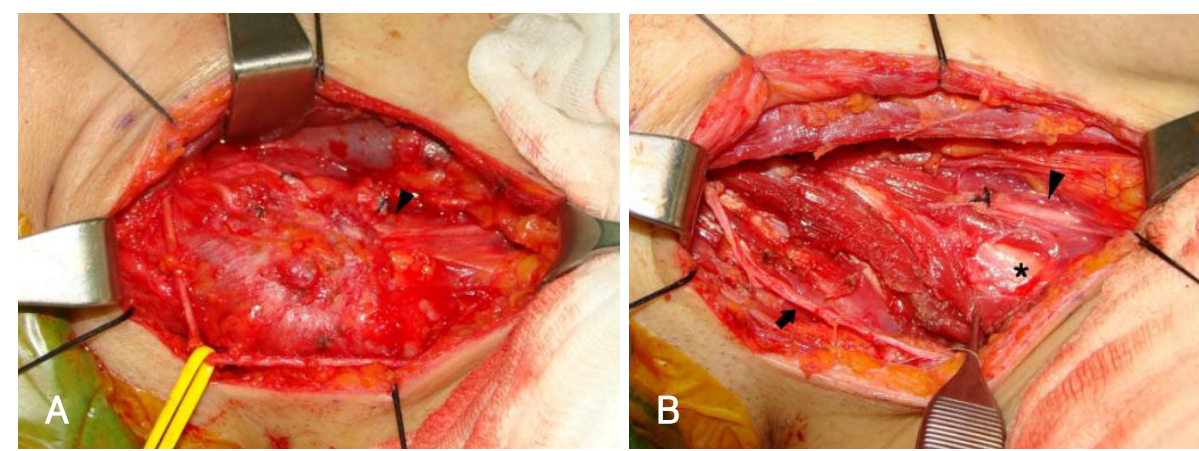

Fig. 2. Intraoperative photographs. After fibrofatty tissue in level $\mathrm{V}$ was removed, poorly defined mass in the levator scapular muscle is observed. This mass entraps phrenic nerve (arrow)(A). After mass removal, spinal accessory nerve (arrow) and brachial plexus (asterix) remain intact but phrenic nerve (arrowhead) is resected with tumor (B).

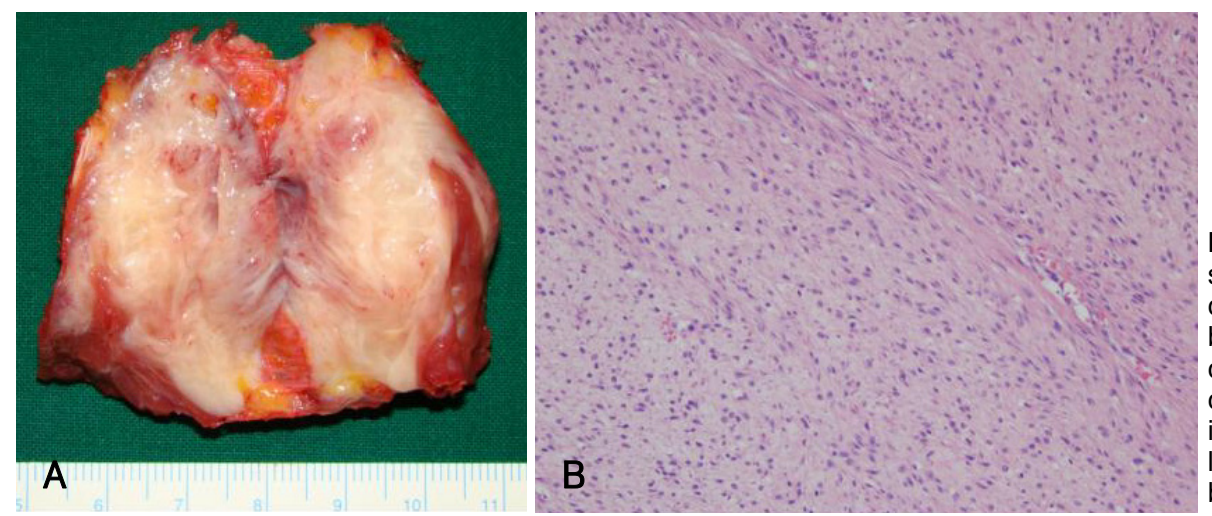

Fig. 3. The gross appearance of surgical specimen shows a poorly circumscribed firm, gray-white, rubbery mass and whorling appearance (A). The histologic study reveals collections of uniform-appearing, spindle-shaped cells grouped in poorly defined fascicles and separated by collagen strands $(H \& E, \times 200)(B)$. 
유육종(fibrosarcoma grade I) 등 다양한 용어로 불리고 있 다. ${ }^{7)}$ 육안적으로 마치 건(tendon)과 같은 모양을 하고 있어 유건종(desmoid tumor)으로 흔히 불린다.

섬유종증은 인구 백만명 당 2.4 4.3명의 발생빈도를 보이 는 매우 드문 질환으로 3 분의 1 정도가 복강 외에서 발생한 다. ${ }^{8)}$ 또한 전체 섬유종증의 $12 \%$ 정도가 두경부 영역, 특히 경부에 흔히 발생한다. ${ }^{9}$

Enzinger와 Weiss는 섬유종증을 발생 위치에 따라 천 층형과 심부형으로 구분하였다. 천층형 섬유종증은 손바닥 이나 발바닥 등에 신체 표면에 병변이 있는 경우를 칭하며, 심부형 섬유종증은 복강내(intraabdominal) 아형과 복강외 (extraabdominal) 아형으로 구분된다. 이들의 분류에 따르 면 두경부에 발생하는 섬유종증은 복강외에 발생한 심부형 섬유종증이 된다. ${ }^{3)}$

섬유종증의 발병기전에 대해서 여러 가설이 있다. 섬유 종증 환자의 많은 수에서 수술 등 외상의 병력이 있는데, 수 술 부위의 미성숙 섬유아세포가 증식하면서 종양을 형성한 다 가설이다. 임신 혹은 에스트로겐이 높은 경우에 섬유종증 의 증식이 가속되는 경향은 호르몬과의 연관성도 시사한다. 또한 가드너 증후군(Gardner syndrome)과 같은 유전질 환에서 섬유종증의 유병률이 높은 것으로 보고되고 있다. 이와 같이 외상, 호르몬 연관련, 유전인자 등이 섬유종증의 병인으로 거론되고 있으나 명확하지는 않다. ${ }^{1-3)}$

섬유종증의 진단은 절제 후 조직검사를 통해서 가능하다. 방추형 세포들로 구성된 섬유다발 사이에 교원섬유속(collagen bundle)이 관찰되는 조직학적 소견을 보인다. 부위에 따라 세포충실도의 차이는 있으나 핵의 과염색성(nuclear hyperchromasia)과 세포 이형성이 관찰되지 않아 섬유육종 과 차이가 있다. ${ }^{3)}$ 세침흡인세포검사로는 진단하기에 충분 한 조직을 얻기 어려우나, 본 증례와 같이 16 게이지 이상의 바늘을 이용한 중심부 바늘 생검을 하면 조직학적 진단이 가 능해 치료계획을 세우는 데 도움이 될 것으로 생각된다.

초음파, 전산화단층촬영 등의 영상검사들이 병변의 초기 평가에 흔히 사용되지만 특징적인 소견은 없다. 자기공명 영상은 우수한 연조직 대조능이 있어 병변을 확인하는 데 가장 우수한 영상검사로, 본 증례의 환자에서처럼 $\mathrm{T} 1$ 강조 영상에서는 동일강도를, $\mathrm{T} 2$ 강조영상에서는 불균질의 고 신호강도를 보이며, 조영 증강되는 소견을 보인다. ${ }^{10)}$ 또한 자기공명영상은 치료 후 추적관찰에도 유용하게 사용된다.

섬유종증의 일차 치료는 수술로 병변을 완전히 절제하는 것이다. 하지만 두경부는 해부학적 구조가 복잡하고, 중요 구조물이 인접해 있으며, 병변의 충분한 노출이 제한되어 완전 절제가 어려운 경우가 많다. 이로 인해 두경부의 섬유
종증은 다른 부위에 비해 재발률이 높다. ${ }^{1-3,9,10)}$

절제연에서 종양의 유무는 재발과 연관성이 있어 절제연 이 충분하지 않은 경우에 재발률이 높아 46 62\%까지 보 고되고 있다. ${ }^{1,2,11)}$ 하지만 다른 두경부 종양과 달리 절제연 양성이 재발과 치료결과에 영향이 없다는 보고도 있다. ${ }^{12,13)}$

방사선 치료는 절제 후에도 육안적 잔존암이 있을 때, 재 발한 경우, 수술로 제거하기가 불가능한 경우에 고려해 볼 수 있다. ${ }^{3,9-12)}$ 하지만 미세 잔존종양의 경우 술 후 방사선 치료 는 추가적인 효과가 없다는 보고도 있어 상황에 따라, 특히 소아 환자에서는 경과관찰을 할 수 있다. ${ }^{1,3,14)}$

또한 항에스트로겐 약물인 tamoxifen, testolactone과 같 은 약물이 섬유종증의 치료에 효과가 있다는 보고도 있다. ${ }^{15)}$ 본 증례의 경우 충분한 절제연을 확보하지 못해 술 후 방사 선 치료를 고려하였으나 환자가 추가치료를 거부하여 정기적 으로 추적관찰을 하기로 하였다.

결론적으로 섬유종증은 악성 질환은 아니지만 주위 조직 을 침범하고 재발을 잘하는 특성이 있으므로 충분한 절제연 을 확보하면서 제거해야 한다. 본 증례에서와 같이 중심부 바 늘 생검과 자기공명영상을 통해 병변의 조직학적 진단 및 범 위를 미리 확인하고 치료하는 것이 종양의 재발을 줄이는 데 도움이 될 것으로 생각된다.

\section{REFERENCES}

1) Hoos A, Lewis JJ, Urist MJ, Shaha AR, Hawkins WG, Shah JP, et al. Desmoid tumors of the head and neck--a clinical study of a rare entity. Head Neck 2000;22 (8) :814-21.

2) Wang CP, Chang YL, Ko JY, Cheng CH, Yeh CF, Lou PJ. Desmoid tumor of the head and neck. Head Neck 2006;28 (11):1008-13.

3) Siegel NS, Bradford CR. Fibromatosis of the head and neck: a challenging lesion. Otolaryngol Head Neck Surg 2000;123 (3) :269-75.

4) Shin KS, Uhm KI, Lee YH, Lew JD. Aggressive fibromatosis arising in temporal muscle. Yonsei Med J 1986;27 (2):155-8.

5) Kim KM, Han JW, Kim HS, Suh JW. A case of infantile fibromatosis of neck. Korean J Otolaryngol-Head Neck Sung 1999;42 (7) :927-31.

6) Park BJ, Kim JH, Kim TH, Kim SH. A case of adult onset fibromatosis arising in submental region. Korean J Otolaryngol-Head Neck Sung 2003;46(4):345-8.

7) Batsakis JG, Raslan W. Extra-abdominal desmoid fibromatosis. Ann Otol Rhinol Laryngol 1994;103 (4 Pt 1):331-4.

8) Conley J, Healey WV, Stout AP. Fibromatosis of the head and neck. Am J Surg 1966;112 (4):609-14.

9) Masson JK, Soule EH. Desmoid tumors of the head and neck. Am J Surg 1966;112(4):615-22.

10) Castellazzi G, Vanel D, Le Cesne A, Le Pechoux C, Caillet H, Perona $\mathrm{F}$, et al. Can the MRI signal of aggressive fibromatosis be used to predict its behavior? Eur J Radiol 2009;69 (2) :222-9.

11) Posner MC, Shiu MH, Newsome JL, Hajdu SI, Gaynor JJ, Brennan MF. The desmoid tumor not a benign disease. Arch Surg 1989; $124(2): 191-6$

12) Fasching MC, Saleh J, Woods JE. Desmoid tumors of the head and neck. Am J Surg 1988;156 (4):327-31.

13) Catton CN, O’Sullivan B, Bell R, Cummings B, Fornasier V, Pan- 
zarella T. Aggressive fibromatosis: optimisation of local management with a retrospective failure analysis. Radiother Oncol 1995;34 (1) :1722.

14) Merchant NB, Lewis JJ, Woodruff JM, Leung DH, Brennan MF.
Extremity and trunk desmoid tumors: a multifactorial analysis of outcome. Cancer 1999;86 (10):2045-52.

15) Sciarra F. Anti-estrogens and aromatase inhibitors: tamoxifen and testolactone. J Endocrinol Invest 1988;11 (10):755-62. 